\title{
Metode Pembenihan Ikan koi Cyprinus carpio dalam menghasilkan benih berkualitas di Mizumi Koi Farm, Kabupaten Sukabumi, Jawa Barat.
}

\section{Method of Hatchery for koi Cyprinus carpio to produce quality seeds at Mizumi Farm, Sukabumi, West Java.}

\author{
Andri Hendriana ${ }^{1}$, Fajar Ridwansyah ${ }^{1}$, Andri Iskandar ${ }^{1}$, Asep Syamsul Munawar ${ }^{2}$, Deni \\ Lugina $^{2}$ \\ ${ }^{1)}$ Program Studi Teknologi Produksi dan Manajemen Perikanan Budidaya, Sekolah Vokasi, \\ Institut Pertanian Bogor, Bogor \\ ${ }^{2)}$ Mizumi Koi Farm, Kabupaten Sukabumi \\ E-mail: andri.hendriana@apps.ipb.ac.id
}

\begin{abstract}
ABSTRAK
Ikan koi merupakan salah satu komoditas ikan hias yang populer dibudidayakan di Indonesia. Ikan ini memiliki daya tarik karena warnanya yang sangat indah dan sering dijadikan sebagai ikan kontes. Setiap tahunnya permintaan ikan koi terus meningkat baik di pasar dalam maupun di luar negeri, sehingga ikan ini memiliki prospek usaha yang menjanjikan. Salah satu prospeknya yaitu pada kegiatan pembenihan yang meliputi kegiatan persiapan wadah, pemeliharaan induk, pemijahan induk, penetasan telur, pemeliharaan larva, pemeliharaan benih, pemeliharaan sangkal, pengelolaan kualitas air, pencegahan hama dan penyakit, serta pemanenan. Salah satu sentra pembenihan ikan koi yaitu Mizumi Farm yang berlokasi di Sukabumi, Jawa Barat. Produktivitas ikan koi di lokasi tersebut diantaranya jumlah telur yang dihasilkan sekitar 116.452 butir, fertilization rate (FR) $81 \%$, hatching rate (HR) $75 \%$, survival rate (SR) larva 63\%, SR benih/putihan sebesar 63\% dan SR sangkal sebesar $74 \%$. Ikan yang dihasilkan berjumlah 634 ekor dengan ukuran $5 \mathrm{~cm}$. Pemasaran benih ikan koi di Mizumi Farm diantaranya mitra binaan, penghoby daerah Sukabumi dan kota lain.

Kata Kunci: Ikan Koi, Pembenihan, Produktivitas
\end{abstract}

\section{PENDAHULUAN}

Indonesia memiliki sumberdaya alam yang baik dalam mendukung pengembangan budidaya ikan terutama ikan hias. Ikan koi merupakan salah satu ikan hias yang banyak diminati oleh masyarakat dalam maupun luar negeri. Para penggemar ikan koi tidak hanya memelihara namun juga ikut serta dalam kontes sehingga dapat menaikan gengsi bagi pemiliknya (Yuli dan Triyanti 2012).

Menurut Direktorat Jenderal Perikanan Budidaya (2015), ikan yang berasal dari negara lain dan mudah didomestikasi serta cukup popular dibudidayakan di Indonesia yaitu ikan koi. Produksi ikan koi pada tahun 2019 triwulan III sebanyak 361.405 ekor dari produksi yang ditargetkan sebanyak 241.500 ekor (DJPB 2019). Nilai ekspor ikan koi di Indonesia terus mengalami peningkatan yaitu di tahun 2010 dengan nilai ekspor sekitar 12 juta dolar meningkat menjadi 20 juta dolar di tahun 2011 dan nilai ekspor ikan koi telah meningkat pada tahun 2016 mencapai 65 juta dolar. Peningkatan pasar terhadap ikan koi memacu pembudidaya ikan koi untuk meningkatkan usaha budidayanya (Ulfiana 2012). 


\section{METODE}

Kegiatan pembenihan ikan koi dilaksanakan pada tanggal 6 Januari-19 Februari 2020 di Mizumi Koi Farm, Kabupaten Sukabumi, Jawa Barat. Metode yang dilakukan dalam kegiatan ini adalah mengikuti dan melakukan secara langsung seluruh kegiatan, melakukan pengamatan serta observasi, melakukan wawancara dengan pihak-pihak yang berkompeten di bidangnya, melakukan pencatatan dan mengumpulkan informasi-informasi serta studi pustaka materi terkait.

\section{HASIL DAN PEMBAHASAN}

Persiapan Wadah Pemeliharaan Induk. Wadah yang digunakan dalam pemeliharaan induk koi yaitu kolam beton berbentuk bulat dengan diameter $5 \mathrm{~m}$ dan tinggi $2 \mathrm{~m}$. Kegiatan persiapan wadah meliputi penyurutan air, pembersihan wadah dan filter, pembilasan dan pengisian air. Penyurutan air dilakukan dengan cara membuka saluran outlet bak. Pembersihan bak dan filter dilakukan dengan cara menyikat bagian dinding bak agar tidak ada lumut atau kotoran yang menempel pada bak, lalu bak dibilas dengan air bersih dengan cara membuka saluran inlet, kemudian bak di keringkan selama satu hari. Bak yang sudah dikeringkan kemudian diisi air dengan ketinggian air 1,9 m.

Penebaran Induk. Induk yang terdapat di Mizumi Koi Farm berasal dari hasil pemuliaan induk sendiri dengan jenis Showa, Kohaku, Ki utsuri, Hi utsuri dan Shiro. Penebaran induk dilakukan dengan cara aklimatisasi selama 5-10 menit, kemudian induk dikeluarkan dengan cara membuka plastik kemas dan dibiarkan keluar secara perlahan. Induk yang ditebar memiliki ciri induk unggul yaitu memiliki pola warna konsisten, bentuk tubuh proposional dan tidak cacat. Induk jantan dan betina dipelihara pada wadah yang berbeda untuk mencegah adanya kawin liar. Jumlah induk yang ditebar sebanyak 10 ekor jantan dan 10 ekor betina. Induk yang sudah matang gonad akan menghasilkan benih yang kualitas dan kuantitasnya baik (Kurniawan et al. 2013).

Pemberian Pakan Induk. Pakan merupakan salah satu faktor yang mempengaruhi keberhasilan pemijahan, baik dari kualitas maupun kuantitas telur yang dihasilkan. Pakan yang digunakan yaitu pelet berukuran $5 \mathrm{~mm}$ dengan metode pemberian pakan secara ad satiation dan frekuensi pemberian pakan dua kali sehari yaitu pada pagi dan sore hari. Menurut Kusrini et al. (2015) pakan induk diberikan dua kali sehari secara ad satiation, dengan jenis pakan pelet komersial yang mengandung protein minimal $35 \%$. Kandungan nutrisi pakan induk yang dipelihara disajikan pada Tabel 1.

Tabel 1. Kandungan nutrisi pakan induk

\begin{tabular}{cc}
\hline Komponen & Kandungan $(\%)$ \\
\hline Protein & 35 \\
Lemak & 5 \\
Serat & 3 \\
Abu & 12 \\
Kadar Air & 12 \\
Kalsium & 2 \\
\hline
\end{tabular}

Sumber : CP Petfood

Pencegahan Hama dan Penyakit. Pencegahan hama dengan cara menangkapi hama, pemasangan pagar mengelilingi lingkungan pemeliharaan, dan pemasangan jaring pada wadah pemeliharaan. Ikan yang terinfestasi akan berenang dekat permukaan, berada dipinggir kolam dan nafsu makan menurun (Karantina Ikan Kelas I 2009). Gejala ikan terjangkit penyakit yaitu warnanya lebih gelap, tubuhnya menjadi kurus, dan sering menggesek tubuhnya ke dinding kolam. Pencegahan hama dan penyakit pada induk tidak dilakukan secara spesifik karena belum pernah terjadi masalah kematian ikan yang disebabkan oleh penyakit, namun pencegahan yang dilakukan yaitu dengan cara pemberian pakan dan manajemen kualitas air yang baik. 
Hendriana dkk : Metode Pembenihan Ikan koi Cyprinus carpio dalam menghasilkan benih ...

Tabel 2. Hasil rata rata pengukuran kualitas air wadah induk

\begin{tabular}{ccc}
\hline Parameter & Nilai & Baku Mutu \\
\hline Suhu $\left({ }^{\circ} \mathrm{C}\right)$ & $23-26$ & $20-28$ \\
$\mathrm{pH}$ & $7,1-7,5$ & $6,5-8$ \\
DO $(\mathrm{mg} / \mathrm{L})$ & $5,5-6,5$ & $>5$ \\
Amonia $(\mathrm{mg} / \mathrm{L})$ & 0,01 & $<0,03$ \\
\hline
\end{tabular}

Manajemen Kualitas Air. Kualitas air merupakan faktor paling menentukan dalam proses produksi ikan karena air merupakan media hidup ikan (Lastuti et al. 2000). Pengelolaan kualitas air bertujuan agar kualitas air selalu terjaga dan sesuai standar kualitas air untuk ikan koi. Pengelolaan kualitas air dilakukan menggunakan sistem resirkulasi. Pengecekan kualitas air dilakukan seiap satu minggu sekali dengan parameter yaitu suhu, $\mathrm{pH}, \mathrm{DO}$ dan amonia. Hasil rata rata pengukuran kualitas air wadah induk disajikan pada Tabel 2.

Persiapan Wadah Pemijahan. Wadah yang digunakan pada pemijahan yaitu bak beton berukuran $3 \mathrm{~m} \times 2,5 \mathrm{~m} \times 1 \mathrm{~m}$ dengan tinggi air $0,7 \mathrm{~m}$. Bak ini dilengkapi saluran inlet, saluran outlet, dan sistem aerasi. Langkah pertama dalam persiapan wadah yaitu pipa saluran inlet dibuka untuk penyurutan air, kemudian wadah dibersihkan menggunakan sikat dengan menggosok dinding kolam dan dasar kolam. Kolam dibilas kembali hingga bersih dan dikeringkan. Bak diisi air setelah dikeringkan selama satu hari dengan cara membuka pintu inlet hingga bak terisi dengan ketinggian air $0,7 \mathrm{~m}$. Bak yang sudah terisi air dilakukan pengukuran suhu, jika suhu dibawah $22^{\circ} \mathrm{C}$ maka ditambahkan water heater hingga suhu $>22^{\circ} \mathrm{C}$. Bak dipasang hapa berukuran $3 \mathrm{~m} \times 3 \mathrm{~m}$ yang diikat diujung dan sisi bak, dengan tiap ujung hapa diberi pemberat berupa besi agar hapa tidak mengapung dan menganggu pada proses pemijahan. Pemasangan kakaban berfungsi sebagai substrat penempelan telur dan bak diberi aerasi sebanyak 3 titik.
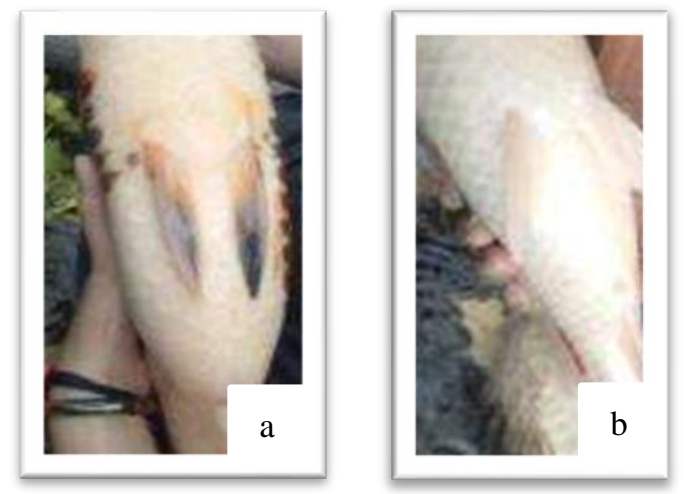

Gambar 1. Seleksi induk matang gonad: (a) induk betina, (b) induk jantan.

Seleksi Induk Matang Gonad. Seleksi induk matang gonad dilakukan secara observasi dan visual terhadap stock induk. Menurut Bastian (2018), umur ikan dipijahkan berkisar 2 tahun untuk induk betina (Gambar 1a) dengan bobot $2 \mathrm{~kg} / \mathrm{ekor}$, sedangkan induk jantan berumur 1 tahun dengan bobot $1 \mathrm{~kg} / \mathrm{ekor}$ (Gambar 1b). Parameter induk koi matang gonad disajikan pada Tabel 3

Tabel 3. Parameter induk ikan koi matang gonad

\begin{tabular}{|c|c|c|}
\hline Parameter & Betina & Jantan \\
\hline Umur & Minimal 2-3 tahun. & Minimal 1,5 - 2 Tahun \\
\hline Gerakan & Lamban & Lincah \\
\hline Genital & $\begin{array}{l}\text { Kelamin berwarna kemerah-merahan dan } \\
\text { Membulat. }\end{array}$ & $\begin{array}{l}\text { Jika perut diurut kearah anus akan keluar } \\
\text { cairan sperma }\end{array}$ \\
\hline $\begin{array}{l}\text { Bentuk } \\
\text { Tubuh }\end{array}$ & $\begin{array}{l}\text { Ukuran tubuh relatif Lebih besar, perut membesar } \\
\text { sampai batas anus dan apabila ditekan terasa } \\
\text { lembek/lunak, sisik lebih jarang pada bagian perut. }\end{array}$ & Relatif lebih kecil dan langsing \\
\hline
\end{tabular}


Pemijahan. Pemijahan dilakukan menggunakan teknik pemijahan secara alami dengan sex ratio antara jantan dan betina 1:1. Penebaran induk dilakukan pada pagi hari. Menurut Ismail dan Khumaidi (2016), waktu pelepasan induk yang baik yaitu pada waktu pagi dan sore hari karena pada waktu tersebut suhu perairan cenderung rendah. Jaring penutup dipasang pada bak pemijahan untuk mecegah induk loncat. Ikan akan memijah pada petang hingga terbit fajar. Pada kegiatan pemijahan induk akan lebih senang berada di bawah substrat alami yang berada di bak yang digunakan sekaligus untuk menempelkan telur-telurnya (Suseno 2002). Pada saat pemijahan berlangsung ikan jantan mengejar ikan betina sampai betina melakukan ovulasi yang bersamaan dengan jantan akan mengeluarkan sperma. Induk diangkat pada pagi hari setelah proses pemijahan. Data bobot induk sebelum dipijahkan disajikan pada Tabel 4.

Pengangkatan Induk. Pengangkatan induk dilakukan setelah induk selesai memijah. Metode yang digunakan yaitu dengan cara induk diangkat perlahan menggunakan serokan lalu dimasukan ke plastik kemas. Induk dikarantina terlebih dahulu di bak karantina selama 1 hari. Sebelum ditebar ke bak karantina induk ditimbang terlebih dahulu. Tujuan lain karantina agar induk tidak membawa patogen ke bak induk. Data bobot induk sesudah dipijahkan disajikan ada Tabel 4.

Tabel 4 Data bobot induk sebelum dan sesudah dipijahkan

\begin{tabular}{cccc}
\hline \multirow{2}{*}{ Pemijahan } & \multicolumn{2}{c}{ Betina $(\mathrm{g})$} \\
\cline { 2 - 4 } & Jantan $(\mathrm{g})$ & Sebelum & Sesudah $(\mathrm{g})$ \\
\hline 1 & 3.129 & 3.565 & 3.274 \\
2 & 3.209 & 3.638 & 3.282 \\
3 & 3.216 & 3.592 & 3.261 \\
\hline
\end{tabular}

Penetasan Telur. Wadah yang digunakan untuk penetasan telur merupakan wadah yang sama dengan wadah pemijahan. Telur yang terbuahi berwarna kuning, sedangkan telur yang tidak terbuahi berwarna putih susu. Kematian telur disebabkan oleh beberapa faktor antara lain pembuahan yang tidak sempurna dan kondisi telur yang saling menempel atau saling tindih saat penyebaran di waring sehingga sirkulasi oksigen terganggu dan menyebabkan kematian (Setyono 2009). Telur yang menetas menjadi larva dipelihara selama 7 hari di kolam pemijahan. Metode perhitungan Fertilisation Rate (FR) menggunakan rumus (Waynarovich dan Hoart 1980). Hasil pengukuran jumlah telur, selisih bobot, FR dan HR disajikan pada Tabel 5.

Tabel 5. Data jumlah dan rata rata telur, FR dan HR

\begin{tabular}{lcccc}
\hline \multicolumn{1}{c}{ Komponen } & Pemijahan 1 & Pemijahan 2 & Pemijahan 3 & Rata - rata \\
\hline Selisih bobot induk (g) & 384,93 & 379,20 & 382,53 & 382,21 \\
Jumlah telur/1(g) (butir) & 351 & 361 & 351 & 344 \\
Jumlah telur (butir) & 114.075 & 128.516 & 116.843 & 116.452 \\
FR (\%) & 81 & 82 & 80 & 81 \\
HR (\%) & 72 & 76 & 75 & 75 \\
SR (\%) & $60 \%$ & $64 \%$ & $65 \%$ & $63 \%$ \\
\hline
\end{tabular}

Hasil penetasan telur ikan koi menghasilkan rata-rata FR sebesar $81 \%$ dan HR sebesar $75 \%$. Nilai dari kedua parameter tersebut menunjukkan bahwa kegiatan penetasan sangat baik. Menurut Richter dan Rustidja (1985) bahwa presentase penetasan ikan koi secara normal berkisar antara 50- 80\%.

Persiapan Wadah Pemeliharan Larva. Wadah yang digunakan pemeliharaan larva sama dengan benih yaitu kolam semi permanen berukuran $27 \mathrm{~m}$ x $22 \mathrm{~m}$ x $2 \mathrm{~m}$. Persiapan wadah pemeliharaan larva dan benih meliputi penyurutan air, pengambilan sampah dan hama, pembalikan tanah, pengeringan tanah, pengapuran dan pengisian air. Langkah pertama persiapan wadah yaitu penyurutan air dengan cara menyumbat pipa inlet menggunakan plastik atau pipa L yang dihadapkan keatas untuk membuka pipa outlet. Pengambilan sampah dan hama dilakukan dengan cara memunguti sampah, keong, telur keong dan membersihkan lumut yang merambat di area kolam. Pembalikan tanah dilakukan dengan 
Hendriana dkk : Metode Pembenihan Ikan koi Cyprinus carpio dalam menghasilkan benih ...

cara menyeret sirib selama satu bulan. Pengapuran dilakukan seminggu sebelum penebaran benih, menggunakan jenis kapur pertanian dosis $50 \mathrm{~g} / \mathrm{m}^{2}$. Pengapuran bertujuan untuk memutus siklus penyakit dan menurunkan kadar pH pada wadah pemeliharaan. Menururt Boyd (1982) kapur dolomit memiliki kemampuan untuk meningkatkan $\mathrm{pH}$ tanah. Kapur ditebar secara merata keseluruh dasar kolam pemeliharaan. Pengisian air pada kolam diisi setinggi $0,7 \mathrm{~m}$ setelah pengapuran tutup saluran outlet dan membuka saluran inlet untuk pengisian air. Penambahan probiotik dilakukan dengan cara menambahkan satu botol EM4 kemudian dicampurkan air sebanyak 10 L dan EM4 satu botol. EM4 dan air $10 \mathrm{~L}$ diaduk hingga rata kemudia ditebar secara menyeluruh ke wadah pemeliharaan yang bertujuan untuk menambah probiotik pada wadah pemeliharaan. Menurut Irianto (2007), aplikasi pemberian probiotik dalam akuakultur dapat diberikan secara langsung melalui media air.

Pemberian Pakan Larva. Menurut Saputra (2011), larva ikan merupakan fase yang paling kritis dalam budidaya ikan karena mempunyai ketahanan yang kurang baik dan rentan pada perubahan kondisi lingkungan. Cadangan makanan pada larva akan habis setelah 48 jam menetas, sehingga diperlukan asupan gizi tambahan. Pakan yang diberikan berupa kuning telur yang telah direbus matang dan diayak menggunakan saringan sampai merata. Menurut Priyadi et al. (2010) persyaratan pakan sesuai untuk larva adalah berukuran kecil, dan lebih kecil dari bukaan mulut larva. Frekuensi pemberian pakan sehari sekali yang diberikan pada pukul 07.30 WIB secara merata.

Pemanenan Larva. Pemanen larva dilakukan setelah pemeliharaan di bak pemijahan selama tujuh hari. Pemanenan dilakukan dengan cara mengangkat kakaban yang terpasang di dalam wadah pemijahan kemudian disiram air untuk mencegah larva yang tersangkut di dalam kakaban terangkat lalu larva diserok menggunakan seser dan dimasukan ke dalam ember plastik untuk melakukan grading.

Tingkat kelangsungan hidup larva dihitung menggunakan rumus (Nimrat et al 2011):

$$
\mathrm{SR}=\frac{N t}{N o} x 100 \%
$$

SR = Derajat kelangsungan hidup $(\%)$

$\mathrm{Nt} \quad=$ Jumlah ikan pada akhir pemeliharaan (ekor)

No = Jumlah ikan pada awal pemeliharan (ekor)

Grading Larva. Grading larva (Gambar 3a) dilakukan setelah larva berumur tujuh hari, dimana grading bertujuan untuk memisahkan larva yang berwarna hitam dan berwarna putih. Larva yang diambil adalah larva yang berwarna hitam karena kemungkinan akan menghasilkan koi jenis Showa. Jumlah ikan dan SR larva hitam yang dihasilkan dari pemijahan sebanyak 14.599 ekor atau 26,9\%. Larva hitam yang sudah di grading ditebar di kolam pembenihan, sedangkan larva putih di restocking di tempat wisata kampung Cisitu. Grading dilakukan dengan cara menyerok larva menggunakan seser, lalu seser simpan di baskom yang terisi air penuh. Larva yang berwarna hitam di sedot menggunakan vakum dan larva putih dipisahkan ke ember lain. Ketika menyedot larva dilakukan penghitungan jumlah larva secara manual. Kegiatan grading dapat berlangsung selama satu sampai dua hari tergantung dari banyaknya jumlah larva yang dihasilkan.

Tabel 6. Jenis pakan ikan koi

\begin{tabular}{|c|c|c|c|c|c|c|}
\hline \multirow{2}{*}{ Jenis pakan } & \multicolumn{6}{|c|}{ Hari } \\
\hline & $1-3$ & 4 & $5-6$ & 7 & $8-30$ & $31-60$ \\
\hline \multicolumn{7}{|l|}{ Egg yolk } \\
\hline \multicolumn{7}{|l|}{ Kuning telur } \\
\hline \multicolumn{7}{|l|}{ Pelet powder + Dedak } \\
\hline Pelet $1 \mathrm{~mm}$ & & & & & & \\
\hline
\end{tabular}


Penebaran Larva. Penebaran larva dilakukan setelah proses grading larva selesai dilakukan. Larva hasil grading (larva hitam) ditebar kedalam wadah pendederan dengan jumlah 14.599 ekor. Larva diangkut menggunakan ember kemudian ditebar secara aklimatisasi selama lima menit setelah itu dimasukan air dari kolam pendederan sedikit demi sedikit (bertujuan agar larva dapat beradaptasi dengan lingkungan yang baru). Penebaran larva dilakukan pada pagi hari untuk menghidari suhu yang tinggi penyebab ikan stres.

Pemberian pakan. Pemberian pakan berguna untuk menumbuhkan dan menimbulkan warna pada benih koi. Pada pemeliharaan awal sampai dengan umur 30 hari diberi pakan pelet powder (kandungan protein 35\%) ditambah dengan dedak. Kebutuhan optimum untuk tumbuh sebesar 30-36\%. Jika protein pakan kurang dari 30\% maka pertumbuhan ikan koi akan terhambat (Natalist 2003). Pada umur ketiga dan keempat, larva diberi pakan rebus kuning telur dengan frekuensi pemberian pakan satu kali sehari pada pagi hari. Pada umur 31 sampai dengan umur 60 hari benih diberi pakan pelet $1 \mathrm{~mm}$ dengan frekuensi pemberian pakan dua kali sehari pada pagi dan sore hari. Pakan yang digunakan menggunakan merek dagang sama dan kandungan yang sama. Hanya ukuran pelet saja yang berbeda karena harus diseusiakan dengan bukaan mulut ikan. Jenis pakan disajikan pada Tabel 6 .

Pengelolaan Kualitas Air. Koi akan hidup jika kualitas air kolam sebagai media dalam keadaan optimal. Kualitas air dapat mempengaruhi kualitas benih yang dihasilkan serta dapat mempengaruhi tingkat kelangsungan hidup ikan. Pengelolaan air yang dilakukan yaitu pengecekan $\mathrm{pH}, \mathrm{DO}$, suhu dan amonia. Pengecekan Suhu, pH dan DO dilakukan setiap seminggu sekali. Pengukuran dilakukan sehari tiga kali yatu pagi pukul 07.30 WIB, siang pukul 13.00 dan sore pukul 16.00 WIB. Pengukuran amonia dilakukan setiap satu bulan sekali menggunakan teskit amonia. Selain pengecekan parameter kualitas air juga dilakukan pergantian air secara terus menerus, penambahan airasi sebanyak tiga titik pada kolam pemeliharaan, dan pengambilan sampah pada saluran inlet atau pinggiran kolam. Data kualitas air pada kolam pembenihan seusai dengan standar baku mutu (SNI 2017). Data rata rata kualitas air air kolam disajikan pada Tabel 7.

Tabel 7. Data rata rata kualitas air

\begin{tabular}{lcc}
\hline \multicolumn{1}{c}{ Parameter } & Nilai & Baku Mutu SNI 2017 \\
\hline Suhu $\left({ }^{\circ} \mathrm{C}\right)$ & $26-28$ & $26-30$ \\
DO $(\mathrm{Mg} / \mathrm{L})$ & $5,9-6,5$ & $>5$ \\
$\mathrm{pH}$ & $7,1-7,5$ & $6,5-8$ \\
Amonia $(\mathrm{Mg} / \mathrm{L})$ & 0,01 & $<0,03$ \\
\hline
\end{tabular}

Pencegahan Hama dan Penyakit. Hama adalah hewan yang mampu menimbulkan gangguan pada ikan, yang terdiri dari predator, pengganggu dan pesaing. Hama yang terdapat pada wadah pemeliharaan larva yaitu ucrit, labi labi, keong dan telur keong. Pemberantasan hama dilakukan dengan cara menangkap dan membuangnya. Patogen yang hidup dalam tubuh koi sangat merugikan karena secara tidak langsung akan mempengaruhi warna ikan koi (Bachtiar 2002). Penyakit yang sering menyerang ikan koi yaitu Koi Herpes Virus (KHV) dan parasit jenis Ichtyoptirius multifilis (White spot). Hartman et al. (2003) menyatakan bahwa ikan yang terserang virus KHV akan mengalami kematian 2448 jam setelah gejala klinis pertama terlihat. Ikan di Mizumi Koi Farm tidak pernah terserang pathogen tersebut karena melakukan pencegahan dengan penerapan biosecurity, dan pengecekan kesehatan dengan mengirimkan sampel ke laboratorium uji BBPBAT Sukabumi.

Pemantauan Pertumbuhan. Pemantauan yang dilakukan yaitu mengkur pertumbuhan mutlak dan pertumbuhan panjang. Pertumbuhan mutlak berdasarkan urutan waktu (Mudjiman 2004) dan pertumbuhan panjang.

Pemantauan pertumbuhan pada larva dan benih ikan koi dilakukan satu minggu sekali untuk mengetahui laju pertumbuhan larva dan benih, baik pertumbuhan bobot rata rata (Gambar 4a) maupun panjang rata rata (Gambar 4b). Menurut Prihadi et al. (2018) pertumbuhan ikan sangat dipengaruhi oleh faktor internal antara lain genetik, aktifitas, spesies, jenis kelamin, umur dan ukuran ikan, kondisi 
Hendriana dkk : Metode Pembenihan Ikan koi Cyprinus carpio dalam menghasilkan benih ...

fisiologi sedangkan faktor eksternal berkaitan dengan lingkungan tempat hidup ikan. Pengambilan sampel pemantauan pertumbuhan dengan cara mengambil secara acak sebanyak 30 ekor.
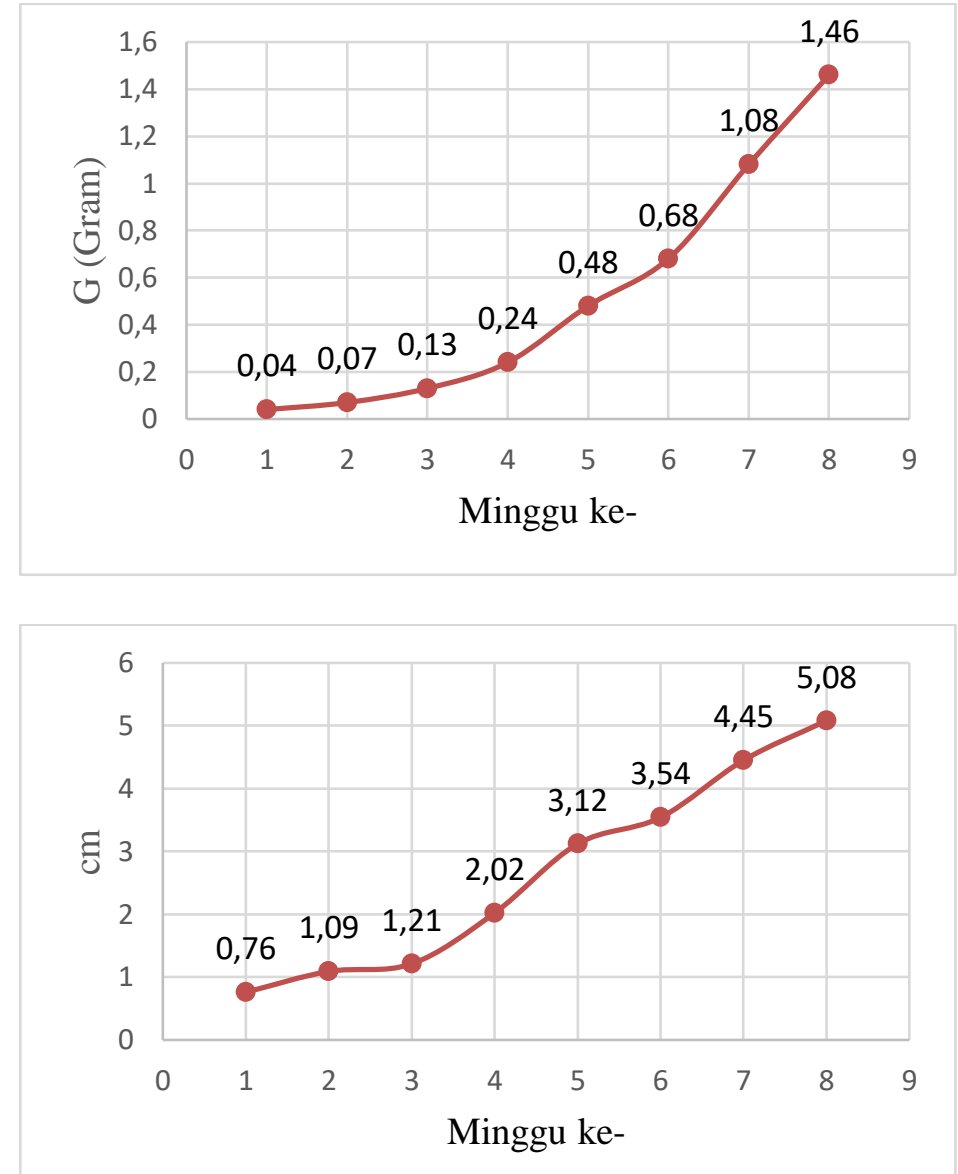

Gambar 4. Pemantauan pertumbuhan : a) bobot rata-rata ikan b) panjang rata rata ikan

Panen benih/Putihan. Pemanenan benih/putihan dilakukan pada benih berukuran 2-3 $\mathrm{cm}$ atau berumur 30 hari. Menurut Agus \& Adi (2007), Panen biasanya dilakukan ketika umumnya telah mencapai 30 hari. Pemanen dilakukan pada pagi hari karena suhu masih stabil. Pemanenan dilakukan dengan cara menutup inlet terlebih dahulu kemudian pipa outlet diganti menggunakan pipa $1 \mathrm{~m}$ (yang sudah dibolongi) dan pipa ditutup mengunakan jaring halus untuk mencegah ikan tidak keluar. Ikan diserok menggunakan sirib untuk memudahkan pengambilan ikan yang berkumpul di kamalir. Ikan yang diserok lalu dimasukan ke plastik kemas untuk dipindahkan ke bak sortasi. Saluran inlet dibuka kembali untuk pengisian air setelah pemanenan selesai. Kegiatan panen putihan bertujuan untuk meng-grading ikan pada umur 30 hari. Data hasil panen putihan disajikan pada Tabel 8.

Tabel 8. Hasil panen benih/putihan

\begin{tabular}{cccc}
\hline Pemijahan & Tebar Larva (ekor) & Panen putihan (ekor) & SR (\%) \\
\hline 1 & 15.225 & 9.644 & 63 \\
2 & 15.650 & 10.032 & 64 \\
Rata- rata & 15.437 & 9.838 & 63 \\
\hline
\end{tabular}

Grading Putihan. Grading putihan dilakukan di bak sortir dengan cara menyaring ikan menggunakan seser lalu dimasukan kedalam ember untuk mengamati pola dan warna ikan. Ikan yang memiliki pola dan warna yang baik akan ditebar kembali untuk dipelihara hingga berumur 60 hari atau ukuran $5 \mathrm{~cm}$. Ikan yang lolos grading dihasilkan jenis Showa dengan rata-rata sebanyak 3.789 atau sekitar 38\% dari jumlah panen putihan. Ikan sisa grading biasanya dilepas liarkan ke Situ Zen. Data hasil Grading putihan disajikan pada Tabel 9. 
Tabel 9. Hasil grading putihan

\begin{tabular}{lccc}
\hline Hasil grading jenis Showa & Pemijahan 1 & Pemijahan 2 & Rata - rata \\
\hline Grading Showa (ekor) & 3.696 & 3.896 & 3.789 \\
\hline
\end{tabular}

Penebaran putihan. Penebaran putihan dilakukan pada pagi hari untuk menstabilkan kondisi air sehingga ikan mudah beradaptasi (Saparinto 2009). Ikan hasil grading ditebar dikolam pendederan yang sama dengan jumlah rata - rata tebar 3.789 ekor. Ikan ditebar menggunakan plastik kemas, dengan cara aklimatisasi terlebih dahulu selama lima menit, kemudian ikan ditebar ke wadah pemeliharaan secara perlahan, hal itu bertujuan agar ikan dapat menyesuaikan diri dengan lingkungan baru

Pemanenan sangkal. Pemanen sangkal dilakukan saat ikan berukuran $5 \mathrm{~cm}$ atau berumur 60 hari. Panen dilakukan pada pagi hari pada saat suhu udara tidak panas sehingga memperkecil tingkat stres. Hal ini sesuai dengan pendapat Handayani, et al. (2007) bahwa panen benih harus dilakukan pada saat suhu air kolam dan udara relatif sejuk, terutama pada pagi hari. Hal ini untuk menekan angka kematian pada ikan saat panen. Pemanenan dilakukan dengan cara menutup saluran inlet dan mengganti saluran outlet dengan pipa $1 \mathrm{~m}$ (yang sudah di bolongi) dan pipa ditutup menggunakan kain halus untuk mencegah ikan terbawa keluar. Setelah ikan berkumpul dikemalir, ikan diserok menggunakan. Ikan yang sudah di serok dimasukan kedalam plastik kemas untuk dibawa kedalam bak sortasi. Nilai ratarata dari hasil pemijahan satu sampai pemijahan dua sebanyak 2.798 ekor dengan SR sebesar 74\%. Data panen dan tingkat SR sangkal dapat dilihat pada Tabel 11.

Tabel 10. Data panen dan tingkat kelangsungan hidup sangkal

\begin{tabular}{cccc}
\hline Pemijahan & Tebar putihan (ekor) & Panen sangkal (ekor) & SR (\%) \\
\hline 1 & 3.686 & 2.753 & 75 \\
2 & 3.893 & 2.844 & 73 \\
Rata- rata & 3.789 & 2.798 & 74 \\
\hline
\end{tabular}

Grading Sangkal. Grading sangkal dilakukan di bak sortir dengan cara menyaring ikan menggunakan seser lalu dimasukan kedalam ember untuk mengamati pola dan warna. Ikan yang memiliki pola dan warna yang baik akan ditebar kembali untuk dipelihara hingga ukuran $12 \mathrm{~cm}$. Data hasil sangkal disajikan pada Tabel 11.

Tabel 11 Hasil grading sangkal

\begin{tabular}{cccc}
\hline Hasil grading sangkal & Pemijahan 1 & Pemijahan 2 & Rata - rata \\
\hline Grading Sangkal (ekor) & 615 & 654 & 634 \\
\hline
\end{tabular}

Pengemasan dan Transportasi. Pada kegiatan pembenihan ikan koi output yang dihasilkan yaitu ikan koi berukuran $5 \mathrm{~cm}$ untuk siap dijual. Transportasi benih dilakukan dengan metode tertutup. Wadah yang digunakan untuk pengemasan yaitu plastik pengepak berukuran $85 \mathrm{~cm} \mathrm{x} 50 \mathrm{~cm}$ dengan tebal 0,07 mm. Menurut SNI 7734 (2017) ikan koi dikemas menggunakan kantong plastik Poli Etilen (PE) 0,5 mm - 0,8 mm rangkap dua. Kegiatan pengemasan yang dilakukan yaitu mengikat ujung plastik agar tidak ada sudut mati dan dibuat dua rangkap untuk mencegah kebocoran, kemudian benih ikan koi dimasukkan kedalam plastik kemas dengan kepadatan 200 ekor/kantong. Plastik yang sudah siap diisi air dan oksigen dengan perbandingan 1:2 lalu diikat menggunakn karet sebanyak 2-3 buah. Ikan yang sudah di kemas selanjutnya di angkut menggunakan mobil.

\section{KESIMPULAN}

Hasil kegiatan pembenihan ikan koi didapatkan jumlah telur rata-rata sebanyak 116.452 butir, FR sebesar $81 \%$, HR sebesar $75 \%$ dan SR larva sebesar 63\%. SR benih/putihan sebesar $63 \%$ dan SR sangkal 74\%. Ikan yang dihasilkan berjumlah 634 ekor dengan ukuran $5 \mathrm{~cm}$. 
Hendriana dkk : Metode Pembenihan Ikan koi Cyprinus carpio dalam menghasilkan benih ...

\section{DAFTAR PUSTAKA}

Agus, \& Adi, A. 2007. Meraih Untung Memelihara Koi. Titian Ilmu Bandung.

Bastian D. 2018. Gila Koi. Jakarta (ID): Brambuse Printing \& Promotion.

Boyd, C. E. and F. Lichtkoppler., 1982. Water Quality Management in Pond Fish Culture.Auburn University: Auburn.

[DJPB] Direktorat Jendral Perikanan Budidadaya. 2019. Laporan Indikator Kinerja Triwulan I. Jakarta (ID). Direktorat Jendral Perikanan Budidaya.

[DJPB] Direktorat Jendral Perikanan Budidaya. 2015. Laporan Tahunan Direktorat Jendral Perikanan Budidaya, Jakarta (ID). Direktorat Jendral Perikanan Budidaya.

Handayani, D, Sucipto, A., Yuniarti, T. 2007. Budidaya Ikan Nila (Oreochromis sp). BBPBAT. Sukabumi.

Ismail, A. Khumaidi. 2016. Teknik Pembenihan Ikan Mas (Cyprinus carpio L.) di Balai Benih Ikan Tenggarang Bondowoso. Jurnal Ilmu Perikanan, 7(1) : 32.

Kurniawan, I. Y., Basuki, F., \& Susilowati, T. 2013. Penambahan Air Kelapa Dan Gliserol Pada Penyimpanan Sperma Terhadap Motilitas Dan Fertilitas Spermatozoa Ikan Mas (Cyprinus Carpio). 2,15 .

Kusrini, E., Cindelaras, S., \& Prasetio, A. B. 2015. Pengembangan Budidaya Ikan Hias Koi (Cyprinus Carpio) Lokal. Balai Penelitian Dan Pengembangan Budidaya Ikan Hias Depok. Media Akuakultur, 10(2), 71.

Lastuti, N.D.r, L.t Suwanti dan G. Mahasri. 2000. Kasus Penyakit Protozoa Ikan Hubungannya dengan Ku alitas Air di Tempat Pembenihan Ikan di Siduarjo Jawa Timur. Lembaga Penelitian. Universitas Airlangga. Surabaya. 23 hal.

Mudjiman, A. 2004. Makanan Ikan. Ed. Revisi. Seri Agriwawasan. Penerbit Penebar Swadaya, Jakarta.

Nimrat S, Boonthai T, Vuthiphandchai V. 2011. Effect of probiotic form, composition of and mode of probiotic administration on rearing of Pacific white shrimp (Litopenaeus vannamei) larvae and postlarvae. Anim Feed Sci Technol. 169: 244-258. doi: 10.1016/j.anifeedsci.2011.07.003.

Priyadi A, Kusrini E, Megawati T. 2010. Perlakuan Berbagai Jenis Pakan Alami untuk Pertumbuhan dan Sintasan Larva Ikan Upside Down Catfish (Synodontis nigriventris).

Richter, C.J.J dan Rustidja. 1985. Pengantar Ilmu Produksi Ikan. Malang : NUFFIC/Unibraw Luw/Fish. Hal. 69-71

Saputra, S.D. 2011. Aplikasi Sistem Resirkulasi Air Terkendali (SRAT) pada Budidaya Ikan Mas (Cyprinus carpio). Fakultas Teknologi Pertanian. Institut Pertanian Bogor. Hal. 5-27.

Setyono B. Pengaruh perbedaan konsentrasi bahan pada pengencer sperma ikan "skim kuning telur" terhadap laju fertilasi, laju penetasan dan sintasan ikan mas (Cyprinus carpio L) Malang (ID): Universitas Muhamadiyah Malang.

SNI. 2017. Syarat Mutu dan Penanganan Ikan Hias Koi (Cyprinus carpio). Jakarta

SNI. 2004. Metode Analisis Kualitas Air. Jakarta.

Suseno, D. 2002. Pengolahan Usaha Pembenihan Ikan Mas. Penebar Swadaya. 
Ulfiana R, G.Mahasri, dan H.Suprapto. 2012. Tingkat Kejadian Aeromonas pada Ikan Koi Cyprinus carpio yang Terinfeksi Myxobolus Koi pada Derajat Infeksi yang Berbeda. Jurnal Ilmiah Perikanan dan Kelautan. 4(2): 169-174.

Woynarovich, E and L. Horvath. 1980. The artificial propagation of warm-water finfishes-a manual for extension. Food and Agriculture Organization of the United Nation. Fish. Tech. Pop. 201p 